\title{
Climate Change and Human Health: A Realistic Outlook from Indian Perspective
}

\section{Sanjoy $\mathbf{R}^{*}$}

Associate Professor, Department of Social Work, University of Delhi, India

*Corresponding author: Dr Sanjoy Roy, Associate Professor, Department of Social

Work, University of Delhi, India, Tel: 9971352017; Email: sanjoyroy30@gmail.com

\section{Perspective \\ Volume 3 Issue 1}

Received Date: December 21, 2018

Published Date: January 07, 2019

DOI: $10.23880 /$ jenr-16000154
Climate change is not only significant and emerging universal environmental challenges and dangerous to public health, but also a threat for mankind now. This issue had its origin in the adoption of the United Nations Framework Convention on Climate Change (UNFCCC) in 1992. Hence, it is finding an increasingly central position on the international agenda as evidenced by the Nobel Prize awarded to the former US Vice President, Al Gore, and a team of UN experts under the chairmanship of Dr. Rajendra K. Pachauri (Director General, The Energy and Resources Institute, New Delhi) for their work on the subject. In 2008, the World Health Organization (WHO) focused on the need to protect health from the adverse effects of climate change. The World Health Day - 2008 theme "Protecting health from climate change" had raised the profile of health dangers posed by global climate variability and change. This issue was selected because overwhelming evidence shows that climate change presents growing threats to international public health security broadly. Climate change occurs over some decades or longer time span. Until now, changes in the global climate have occurred naturally, across centuries or millennia, because of continental drift, various astronomical cycles, variations in solar energy output, and volcanic activity. Over the past few decades or more, it has become increasingly apparent that human actions are changing atmospheric compositions and as a result it causing climate change globally. Actually activities of humankind are altering the world's climate by increasing the atmospheric concentration of energy-trapping gases (greenhouse gases (GHGs), thereby amplifying the natural "greenhouse effect" that makes the Earth habitable. These GHGs comprise, principally, carbon dioxide (mostly from fossil fuel combustion and forest burning) plus other heat-trapping gases such as methane (from irrigated agriculture, animal husbandry, and oil extraction), nitrous oxide, and various human-made halocarbons. Both the developing and developed countries are emitting those gases to the environment directly or indirectly (Graph 1).

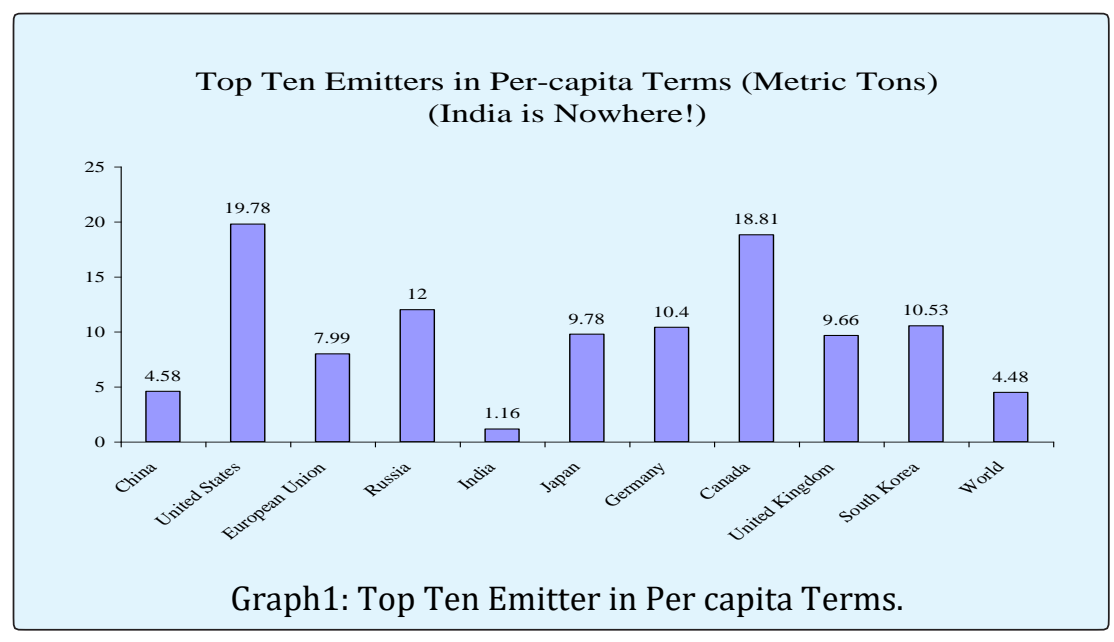


WHO Report [1] if we compare with nearest neighboring country like China, China's emissions are 4.7 times those of India. Even if India could achieve 25 percent improvement over China in energy usage, its emissions will rise to 3.5 times the current Chinese level to reach their current income. With no mitigation obligations, India can sustain $6 \%$ annual growth in percapita GDP. Per-capita income will rise to \$3,260 in 2028 and to $\$ 5,835$ in 2038 in 2008 dollars. With these income levels, people will have shelters that will protect them against floods, droughts and cyclones as well impart mobility in case of natural disasters. With income increases of this order, the government will also have more revenues to build dikes as sea-level rises, move people away from cyclone- and flood-prone zones and build better transport and communication links.

\section{Human Health and Vulnerability}

Scientifically and geographically, the prevalence of some diseases and other threats to human health depend mostly on local climate. Extreme temperatures can lead directly to loss of life, while climate-related disturbances in ecological systems, such as changes in the range of infective parasites, can indirectly impact the incidence of serious infectious diseases. In addition, warm temperatures can increase air and water pollution, which in turn harm human health. We know that human health is strongly affected by social, political, economic, environmental and technological factors, including urbanization, affluence, scientific developments, individual behavior and individual vulnerability (e.g., genetic makeup, nutritional status, emotional well-being, age, gender and economic status). Overwhelming evidence also shows that climate change presents growing threats to public health security from extreme weather-related disasters to wider spread of such vectorborne diseases as malaria and dengue. The impacts of climate on human health will not be evenly distributed around the world.

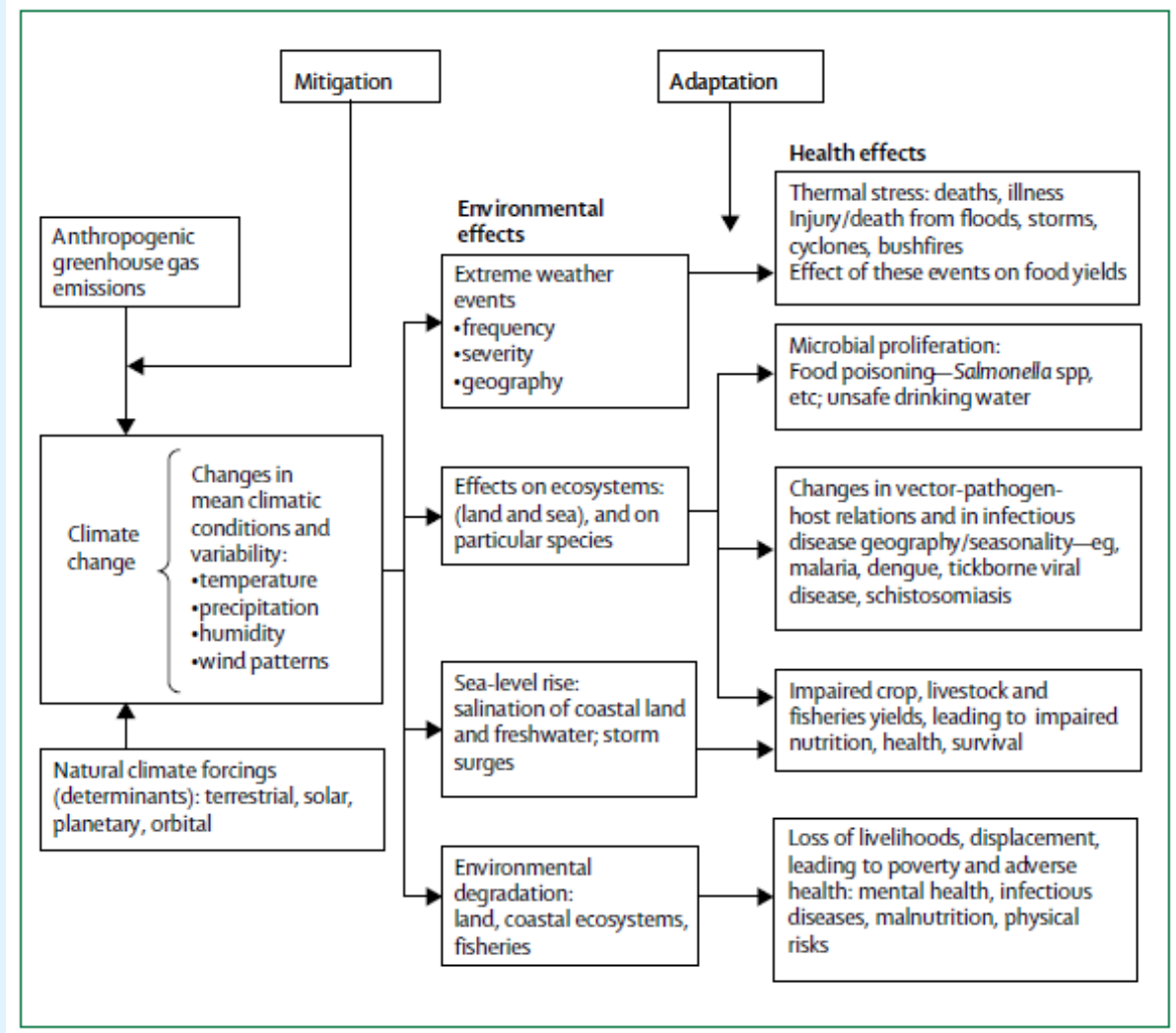

Figure 1: Schematic summary of main pathways by which climate change affects population health. Source: Anthony J McMichael, Rosalie E Woodruff, Simon Hales [3], Climate change and human health: present and future risks, $\mathrm{p}-1-11$. 
The Third Assessment Report (Intergovernmental Panel on Climate Change-2001) [2] showed that vulnerability to climate change is a function of exposure, sensitivity, and adaptive capacity. Developing country populations, particularly in small island states, arid and high mountain zones, and in densely populated coastal areas are considered to be particularly vulnerable.

Mitigation refers to true primary prevention (reducing greenhouse gas emissions). Adaptation (a form of late primary prevention) entails interventions to lessen adverse health effects.

According to the Fourth Assessment Report (2007) of the Intergovernmental Panel on Climate Change (IPCC), the observed effects include $[4,5]$ :

1. The global average surface temperature has increased by approximately $0.65^{\circ} \mathrm{C}$ over the last 50 years.

2. Eleven of the last 12 years (1995-2006) rank among the 12 warmest years since records began in the 1850s.

3 . The rates of warming and of sea level rise have accelerated in recent decades.

4. Many areas, particularly mid- to high-latitude countries, have experienced increases in precipitation and there has been a general increase in the frequency of extreme rainfall.

5. In some regions, such as parts of Asia and Africa, the frequency and intensity of droughts have increased in recent decades.

6. The frequency of the most intense tropical cyclones has increased in some areas, such as the North Atlantic, since the 1970s.

The IPCC has made the following projections for the next century:

1. Global mean surface temperature will rise by $1.1-6.4^{\circ} \mathrm{C}$, depending partly on future trends in energy use. Warming will be greatest over land areas and at high latitudes.

2. Heat waves, heavy precipitation events, and other extreme events will become more frequent and intense.

3. Sea level rise is expected to continue at an accelerating rate.

\section{Vulnerability from Indian Perspectives}

When we talk of India, it is a large developing country with the Great Himalayas, the world's third largest ice mass in the north, $7500 \mathrm{~km}$ long and densely populated coast line in the south. Nearly 700 million of her over one billion population living in rural areas directly depends on climate-sensitive sectors (agriculture, forests, and fisheries) and natural resources (such as water, biodiversity, mangroves, coastal zones, grasslands) for their subsistence and livelihoods. Heat wave, floods (land and coastal), and draughts occur commonly. Malaria, malnutrition, and diarrhea are major public health problems. Any further increase, as projected in weatherrelated disasters and related health effects, may cripple the already inadequate public health infrastructure in the country. Hence, there is an urgent need to respond to the situation. Response options to protect health from effects of climate change include mitigation as well as adaptation.

Climate change will affect human health through different ways directly or indirectly and the impacts will be greater in vulnerable groups like child, young, elderly, medically infirm, poor and isolated population of the society.

\section{Climate Change Affects Human Health by Increasing the Following Incidence}

\section{Heat stress}

2. Respiratory diseases (from increased air pollution)

3. Vector borne diseases

4. Food and water borne diseases

5. Direct injuries and deaths in severe weather events

6. Diseases related to stress, malnutrition and poor sanitation

7. Seasonal pattern of both man-made and natural airborne particles which could lead to asthma.

Scientists in the contemporary time report a high or very high level of confidence that climate change will:

1. Increase malnutrition

2. Increase deaths, injuries and disease from extreme weather events

3. Increase cardio-respiratory disease related to air pollution (especially ground level ozone)

4. Change the ranges of infectious disease vectors

5. Change the range and season of malaria transmission

Malnutrition and micronutrient deficiencies major nutrition related problems could be more in India such as: -Children underweight; $47 \%$

-Children 6-35 months who are anemic; 79.1\%

-Pregnant women age 15-49 who are anemic; 57.8\%

-Ever married women age 15-49 who are anemic; $56.1 \%$

-Ever married men age 15-49 who are anemic; $24.3 \%$

\section{Action Plan by India so far}

Government of India has designed National Mission on Enhanced Energy Efficiency (NMEEE), which is one out of eight missions planned under the National Action Plan on Climate Change. Further, the Expert Committee on Impact 
of Climate Change set up by the Ministry of Environment \& Forests in June 2007 assessed the impact of climate change on six areas, namely Water Resources, Agriculture, Natural Eco-system, Health, Coastal Zone Management and Climate Modeling.

In June 2008 India announced the National Action Plan on Climate Change (NAPCC), a comprehensive framework of mitigation and adaptation policies and programs. India has already released details on three of the eight missions (solar, energy efficiency, and Himalayan ecosystems) that make up the NAPCC, and plans to release details on the other missions in 2010. India also plans to pass legislation setting national carbon dioxide emissions targets and will form a national environmental regulatory agency with the power to enforce emissions standards.

Adaptation to Current and Projected Climate-Related Health Burdens:

-Various National Health Programmes to control diseases being implemented.

-Focus on health promotion and lifestyle diseases increasing.
-Disaster management strengthened.

-Inter-sectoral co-ordination being improved

Besides, a range of policies and programmes have been initiated to address the problem of climate change in the context of sustainable development.

Eight National Missions, form the core of the National Action Plan, representing multi-pronged, long term and integrate strategies has taken for achieving key goals in the context of climate change by India (Table 1). These Missions are

1. National Solar Mission

2. National Mission on Enhanced Energy Efficiency

3. National Mission on Sustainable Habitat

4. National Water Mission

5. National Mission for Sustaining the Himalayan EcoSystem

6. National Mission for Green India

7. National Mission on Sustainable Agriculture and

8. National Mission on Strategic Knowledge for Climate Change

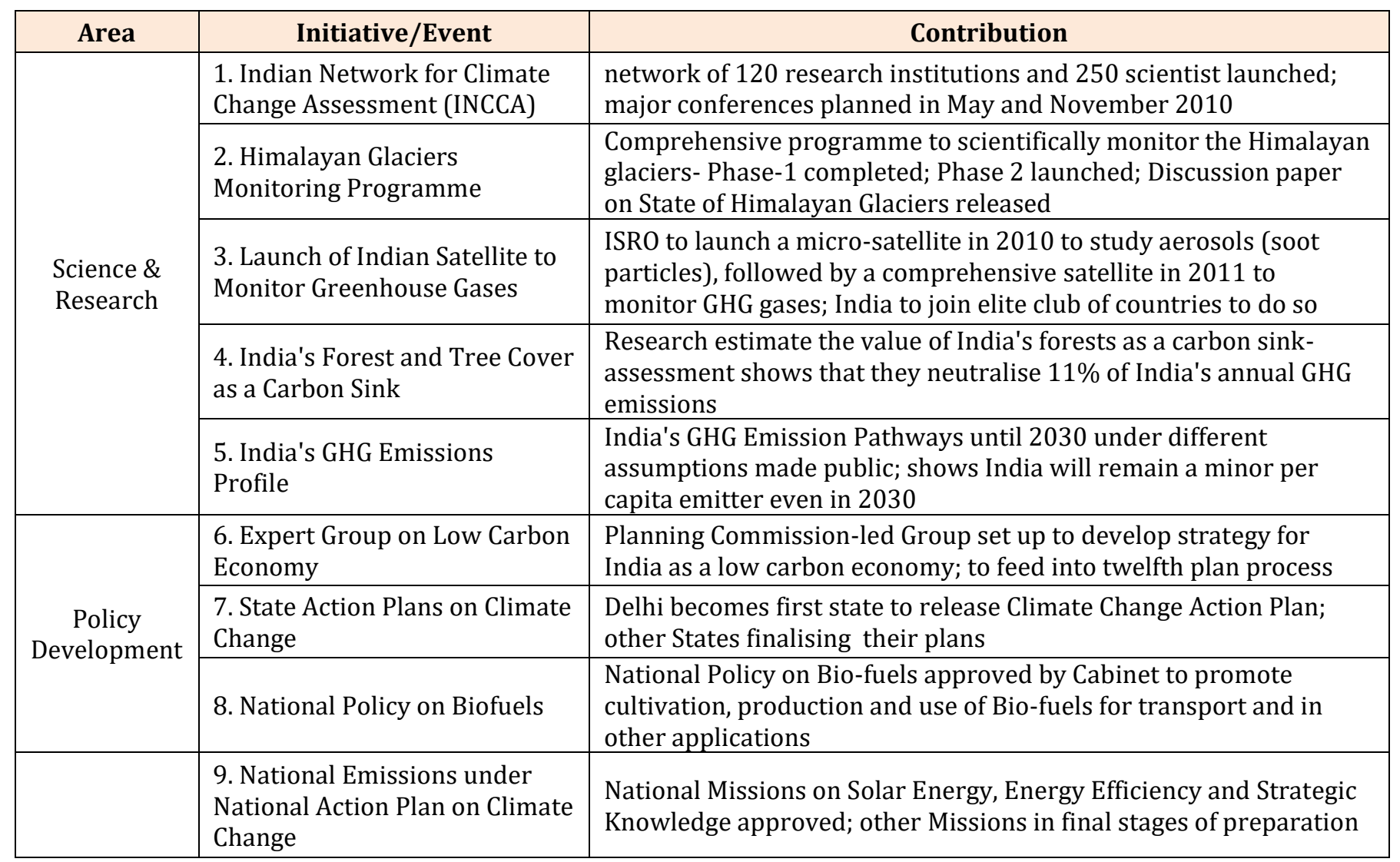




\begin{tabular}{|c|c|c|}
\hline \multirow[t]{5}{*}{\begin{tabular}{c|} 
Policy \\
Implementation
\end{tabular}} & $\begin{array}{l}\text { 10. First National Conference } \\
\text { on Green Building-Materials } \\
\text { and Technologies }\end{array}$ & $\begin{array}{l}\text { Conference to stimulate green building section; to set an example } \\
\text { the Govt proposes that all it new buildings will be GRIHA } 4^{*} \\
\text { compliant subject to site conditions }\end{array}$ \\
\hline & 11. 30 "Solar Cities" & $\begin{array}{l}\text { In-principle approval given to } 30 \text { 'Solar Cities' with aim of } 10 \% \\
\text { deduction in projected demand of conventional energy through a } \\
\text { combination of energy efficiency and renewables }\end{array}$ \\
\hline & $\begin{array}{l}\text { 12. Energy Efficiency Standers } \\
\text { for Appliances }\end{array}$ & $\begin{array}{l}\text { Energy efficiency rating made mandatory for } 4 \text { key appliances - } \\
\text { refrigerators, air conditioners, tubelights and trans formers from } \\
\text { January } 7,2010 \text {; more to follow through } 2010\end{array}$ \\
\hline & 13. Fuel Efficiency Norms & $\begin{array}{l}\text { Plan for fuel economy norms for vehicles announced; to be made } \\
\text { operational in two years }\end{array}$ \\
\hline & 14. CDM Programme & $\begin{array}{l}\text { India assessed as Best CDM Country; Indian projects to neutralise } \\
10 \% \text { of emissions by } 2012\end{array}$ \\
\hline \multirow{4}{*}{$\begin{array}{l}\text { International } \\
\text { Cooperation }\end{array}$} & 15. India to host 'Rio+20' & $\begin{array}{l}\text { India to host 11th COP of Convention on Biodiversity (CBD) in } \\
\text { 2012; mark 20th anniversary of Rio }\end{array}$ \\
\hline & $\begin{array}{l}\text { 16. UN Climate Technology } \\
\text { Conference }\end{array}$ & $\begin{array}{l}\text { India successfully hosts global Conference on technology; Delhi } \\
\text { Statement adopted }\end{array}$ \\
\hline & $\begin{array}{l}\text { 17. SAARC Environment } \\
\text { Ministers Conference }\end{array}$ & $\begin{array}{l}\text { India successfully hosts SAARC Ministers Conference and agrees } \\
\text { joint actions on Climate Change; } 2010 \text { SAARC Summit to be on the } \\
\text { theme of Climate Change }\end{array}$ \\
\hline & $\begin{array}{l}\text { 18. India's Submissions to } \\
\text { UNFCCC }\end{array}$ & $\begin{array}{l}\text { Report documenting India's } 12 \text { proactive submissions to UNFCCC } \\
\text { released }\end{array}$ \\
\hline \multirow{6}{*}{ Forestry } & $\begin{array}{l}\text { 19. State of Forests Report } \\
2009\end{array}$ & $\begin{array}{l}\text { Latest State of Forest Report released; shows continued rise in } \\
\text { India's forest cover }\end{array}$ \\
\hline & 20. Launch of CAMPA & $\begin{array}{l}\text { Ambitious Rs } 11,700 \text { crore (USD } 2.5 \text { Bn) Programme for forest } \\
\text { conservation launched }\end{array}$ \\
\hline & 21. Green India Mission & $\begin{array}{l}\text { New mission under NAPCC to fats-track re-forestation being } \\
\text { finalised }\end{array}$ \\
\hline & $\begin{array}{l}\text { 22. Capacity Building in } \\
\text { Forestry Scheme }\end{array}$ & $\begin{array}{l}\text { New Rs } 369 \text { crore (USD 80Mn) scheme for HRD for forest } \\
\text { personnel }\end{array}$ \\
\hline & $\begin{array}{l}\text { 23. Intensification of Forest } \\
\text { Management }\end{array}$ & $\begin{array}{l}\text { New Rs } 600 \text { crore (USD 125Mn) scheme to improve forest } \\
\text { management, infrastructure, fires, etc. }\end{array}$ \\
\hline & $\begin{array}{l}\text { 24. Inclusion of Forestry within } \\
\text { NREGA }\end{array}$ & $\begin{array}{l}\text { Forestry related activities included as part of India's flagship } \\
\text { employment guarantee scheme to fat-track reforestation; Pilots } \\
\text { being implemented }\end{array}$ \\
\hline
\end{tabular}

Table 1: Recent Contribution of India in the area of Climate Change.

Source: Ministry of Environment \& Forest, GOI [6].

\section{Action on Thermal Plants}

A welcome move taken by this government was the introduction of new emission norms in December 2015 for thermal power plants. Coal-based thermal power plants are notorious for their contributions both to India's worsening air quality as well as Green House Gas emissions that contribute to global warming. The MOEFCC in December 2015 issued a notification requiring all thermal power plants in the country to cut particulate matter emissions by about 40 per cent, sulphur and nitrogen oxides by about 48 per cent, and water consumption by nearly a third within two years of the notification.

India has been lauded at several forums for taking the lead with an ambitious plan to increase renewable energy capacities, not least for the International Solar Alliance (ISA) that India is leading with France. Of the 121 member nations who can join the alliance, 61 have signed the treaty and about 30 have ratified it. The latest to sign was with Netherlands. 


\section{Journal of Ecology \& Natural Resources}

The ISA is a programme that could help in mobilizing funds to shift to solar energy, potentially costing thousands of billions of dollars by 2030. The 1,000 GW plan is in addition to India's own plans to create $175 \mathrm{GW}$ of renewable energy capacity by 2022, of which $58 \mathrm{GW}$ has been achieved so far. By 2030, renewable sources should occupy at least 40 per cent of India's energy mix.

The Indian government has also pledged to spend $\$ 21$ million in the venture from 2016 to 2021, which includes setting up of the headquarters in Gurugram, Haryana. However, there is little clarity on how exactly the ambitious target of $1,000 \mathrm{GW}$ was arrived at or how it will be reached.

According to the 39th report of the Standing Committee on Energy tabled in both houses of the parliament, MNRE could utilise only 63 per cent, 65 per cent and 70 per cent of the total fund allocation during the 2015-16, 2016-17 and 2017-18 (up to December 2017) respectively. The budgetary allocation is usually lower than what MNRE demands, it added. Even that gets reduced during the revised estimates.

In 2016-17, India could meet 68 per cent of the 16,600 MW grid-connected renewable power target. Till December 2017, it had met just 38 per cent of the 14,555 MW target for 2017-18. "Year-on-year non-achievement of the physical targets will derail the entire mission of achieving 175 GW by 2022," warned the report. It adds that while the country is on-track with its wind power commitments, it is lagging behind in solar and biomass energy capacities. According to MNRE, by November 2017, a total of $62 \mathrm{GW}$ of renewable energy capacity has been installed in the country. Of this, $27 \mathrm{GW}$ has been added since May 2014 including $12.87 \mathrm{GW}$ from solar, $11.70 \mathrm{GW}$ from wind, 0.59 from small hydro-power projects and 0.79 from biomass. Solar power in the country had a capacity of $16.6 \mathrm{GW}$ close to the end of last year.

\section{What Katowice, Poland Agreement Reflects?}

Delegates from nearly 200 countries have assembled in Katowice, Poland to try to move the ball forward on battling climate change. A draft text of a final agreement from COP24 has finally emerged but it looks like the talks are dragging on into the weekend.

Among the key pitfalls to emerge overnight was the question of how to establish a functioning international market in carbon credits and whether some countries should get money for damage already caused by climate change? The meeting is also meant to finalize the rulebook for the 2015 Paris climate agreement, provide assurances to poor nations on financial support for tackling global warming.

It covers a lot, laying out a huge new regime not only for the world as a whole to cut its greenhouse gas emissions, but for each individual country to regularly make new emissions-cutting pledges, strengthen them over time, report emissions to the rest of the world and much more. But those 27 pages leave open to interpretation many fine points for how it will all work.

"A number of the developing countries are resisting that kind of model for themselves. They see it as an intrusion on their sovereignty," said Alden Meyer, director of strategy and policy at the Union of Concerned Scientists and one of the many participants in Poland this week. "That's going to be a pretty tough issue at the end of the day." It's hardly the only one. Also unclear is what countries will do after the time frames on their current emissions-cutting promises are up, which for many is 2025 or 2030. Will all countries then start reporting newer and more ambitious promises every five years? Every 10 years? That really matters when five years of greenhouse gas emissions - currently about 40 billion tons of carbon dioxide annually - are capable of directly affecting the planet's temperature. Ultimately the conference was not so successful at the end.

\section{What are the Urgencies Now?}

-Now the urgency to protect the ill effect of climate change is to minimizing greenhouse gas emissions and help developing countries reduce their emissions, and adapting to climate change by reducing their vulnerability.

-For developing country like India need to focus on mainstream and integrate climate change adaptation into development projects through checking current projects whether they are vulnerable to climate change or not, incorporate adaptation to climate change and variability systematically into (existing and new)development projects.

-Official Development Assistance (ODA) funds should be made available for adaptation projects, incorporate impacts and adaptation to climate change into projects and programmes aimed at achieving the MDGs (now SDGs) capacity building related to climate change and foremost focus on adaptation with particular attention to reducing vulnerability of the poor. 
-People should be given awareness related to the vulnerability of climate change and its impact on human health.

-To build the capacity of public health leaders in providing technical guidance on health issues, be competent in developing and implementing strategies for addressing the effects of, and adapting to, climate change, and show leadership in supporting the necessary rapid and comprehensive action.

- To strengthen the capacity of health systems for monitoring and minimizing the public health impacts of climate change through adequate preventive measures, preparedness, timely response and effective management of natural disasters.

-To promote effective engagement of the health sector and its collaboration with all related sectors, agencies and key partners at national and global levels in order to reduce the current and projected health risks from climate change.

On the other hand, the European Union should support more collaborative research projects in order to enable knowledge based adaptation and facilitate knowledge exchange in a science/policy dialogue between EU and developing countries and among developing countries. Lastly, public health, to a large extent, depends on safe drinking water, sufficient food, secure shelter, and good social conditions. A changing climate is likely to affect all these conditions. India has already overburdened health care system will be stretched even further. As individuals, we will undoubtedly experience negative effects on our health and well-being as a result of climate change. Health professionals are also concerned that, in addition to exacerbating current health problems, climate change could also bring new, unexpected challenges in near future.

Scientists say emissions need to drop dramatically by 2030 and reach near-zero by 2050 in order to prevent average global temperatures from rising above 1.5 degrees Celsius (2.7 Fahrenheit) by the end of the century compared to pre-industrial times.

The current draft text presented overnight by the Polish diplomat chairing the talks avoids "welcoming" the Intergovernmental Panel on Climate Change's report on the 1.5-degree target - a possible concession to United States, Russia, Saudi Arabia and Kuwait, who had blocked the endorsement of the study on the first day, angering other countries and environmentalists.

UN Secretary-General, Antonio Guterres challenged the COP24 negotiators to find consensus and "finish the job," warning that climate change was running faster than the negotiators to reverse the trend. "To waste this opportunity in Katowice would compromise our last best chance to stop runaway climate change. It would not only be immoral, it would be suicidal," Guterres warned. He acknowledged that making some tough political decisions was not easy but urged a compromise saying sacrifices will "benefit us all collectively".

\section{The Environment America Approach}

Each Environment America campaign and project aims to protect our planet and our children from global warming a unique way. But they all share a common approach. Each campaign strives to:

Put the environment first. Global warming is an enormous threat. But it's just one symptom of our unhealthy relationship to our environment. To meet the climate challenge, we must put the environment first. Through our research and public education, we're working to shift more hearts and minds over to this point of view.

Take a strategic approach. We must think big and act boldly, but we recognize that progress comes one step at a time. Our focus is on making a difference in public policy and in our lives and our environment, not just making a statement.

Build on what works. We've won policies, actions and decisions that have resulted in reduced carbon pollution across the country. We know which policies work, how they can be improved, and what it takes to win their approval. As always, we're also open to new ideas that work even better.

Work together. We work to unite people from all across the political spectrum around action on global warming, whether it's drivers who want to go electric or small business owners who can benefit from smart climate action programs. Our advocates in Washington, D.C., lobby members of Congress from both parties. Our advocates in the states build coalitions that include doctors and nurses, religious leaders and educators, and people from all walks of life. Our organizers and canvassers engage hundreds of thousands of people. Our members and activists live in all 50 states [7].

The goal is simple. Carbon dioxide is the climate's worst enemy. It's released when oil, coal, and other fossil fuels are burned for energy-the energy we use to power 


\section{Journal of Ecology \& Natural Resources}

our homes, cars, and smartphones. By using less of it, we can curb our own contribution to climate change while also saving money.

\section{References}

1. (2007) WHO Report.

2. Intergovernmental Panel on Climate Change (IPCC). Climate change (2001) The scientific basis. Contribution of working group I to the third assessment report of the Intergovernmental Panel on Climate Change. Cambridge: Cambridge University Press.

3. Anthony JM, Rosalie EW, Simon H (2006) Climate change and human health: present and future risks. In National Centre for Epidemiology and Population
Health, The Australian National University, Canberra 0200, Australia, pp: 1-11.

4. Intergovernmental Panel on Climate Change (IPCC) (2007) Climate Change. The Physical Science Basis. Contribution of Working Group I to the Fourth Assessment Report of the Intergovernmental Panel on Climate Change: Cambridge University Press.

5. Intergovernmental Panel on Climate Change (IPCC) (2007) Climate Change Impacts. Adaptation and Vulnerability Contribution of Working Group II to the Fourth Assessment Report of the Intergovernmental Panel on Climate Change. Cambridge University Press.

6. Ministry of Environment \& Forest, GOI.

7. Environmental Defense. 